\title{
MANAGEMENT OF TRADITIONAL MARKETS IN MANADO
}

\author{
Dotulong Lucky O.H.*, Sumarauw Jacky S.B., Loindong Sjendry S.R. \\ Faculty of Economics, Sam Ratulangi University, Manado, Indonesia \\ ${ }^{\star}$ E-mail: monigre77@gmail.com
}

\begin{abstract}
The purpose of this research is to produce a document that can be used as evaluation material or reference in the framework of planning or decision making made by decision makers in fulfilling regional economic development targets based on the potential resources available in Manado City. This research focuses on disclosing the potential of traditional markets, even though they have traditional local economic characteristics, but the existence of traditional markets is still very feasible to become a profitable and spectacle regional economic potential in increasing regional development even in a modern market climate which is full of various activity facilities. The method used in this research is qualitative research methods. The data obtained from the data sources in this research are: traditional market retailers, traditional market consumers, the people of Manado City who carry out business activities routinely in traditional markets, such as laborers, suppliers of commodity traded in traditional markets, management of traditional markets and scholars. The results of this study have analyzed the various economic benefits of the existence of traditional markets for local communities, especially the people of Manado City; retail business in traditional markets, traditional market consumers, laborers and porters in traditional markets and suppliers of commodity merchandise in traditional markets.
\end{abstract}

\section{KEY WORDS}

Management, traditional markets, community, economic development.

One idea that is still relevant and has the potential for sustainable community economic resilience in the regions is the empowerment of the role of traditional markets. The existence of traditional markets has been able to survive and even play a positive role in facing the global economic crisis.

According to Tumbuan and Shiratake (2010), traditional markets in Indonesia, before the introduction of a payment system by using currency, have served an important role for local residents, that is as a place for job providers either as traders or other jobs related to transaction activities in the traditional market, then became the main transaction place for various types of foodstuffs, clothing, daily necessities, local medicines, local handicrafts and human labor.

Furthermore, the existence of traditional markets is a formal meeting place between farmers (commodity suppliers in traditional markets - people who live in sub-urban areas) and urban residents to carry out various transactions and trade information, especially in the process of buying and selling local products, and local culture is also preserved along with the meeting at the traditional market.

The market can also function as one of the tourist objects where in this place you can find various local products, especially those with local culture, which can attract local and foreign tourists to see this place.

However, it is very unfortunate that currently the existence of traditional markets in many places in various parts of the world, especially in Indonesia, is experiencing an unfavorable situation. The increasing of traditional market retail competitors, such as modern markets (hypermarkets, supermarkets and minimarkets), where the existence of this modern market also sells / trades commodities that are relatively the same as the commodities sold / traded in traditional markets.

This began in 1998 when the Indonesian government lifted the ban on foreign investors from conducting retail business activities in Indonesia through Presidential Decree (Keppres) 
no.99 / 1998 as a result of global free market pressures, especially in the retail sector (Pandin, 2009).

Then, in 2000, still under global free market pressure, the Indonesian government issued Presidential Decree (Keppres) No. 118/2000 regarding providing opportunities for domestic and foreign investors to invest through the modern market retail business.

It was recorded that in 2004 to 2008 the existence of modern markets, especially hypermarkets, increased drastically to reach $40 \%$ per year, supermarkets $10.9 \%$ and minimarkets $16.4 \%$ per year (Pandin, 2009).

Meanwhile, the market share of the modern market for retail food and daily necessities continues to increase, reaching $44.2 \%$ in 2011 , while the market share of traditional markets has decreased.

As a result of the rapid growth and expansion of modern markets in this country, $15 \%$ of the total number of traditional markets located in urban areas in Indonesia must stopped their business (Kompas, 2008).

Based on the existing background, the aims and objectives of this study are:

- How is the role and function of traditional markets for retail business (traders / sellers) in traditional markets, consumers and the people of Manado City who carry out their daily activities related to traditional markets and for local governments?

- Identifying various actual problems that occur in traditional markets in Manado City;

- Providing recommendations for managing sustainable traditional market economic potential for regional economic development in Manado City.

\section{THEORETICAL STUDY}

Regional Economic Development Policy. The aims of development policies and regional development planning is to maximize the level of national income and income per capita of the population. In addition, there are also other objectives such as creating economic development whose results can be seen equally by every component or layer of society, creating a balanced national and state development in various regions, creating optimal employment opportunities and protecting the development of various existing national business activities or companies in Indonesia.

There are many development policies in various developing countries that aim to maximize the increase in national income revenue and income per capita of the population that have sacrificed various important things that are not suitable or are not related to the purpose of the use of funds for increasing national income revenue and income per capita of the population.

These sacrifices are among others in the form of an overhaul of the old social structure, developing technology and modern ways of thinking, as well as an overhaul of the traditional work system which is less disciplined with work procedures that follow certain rules.

Economic development also requires an overhaul in the economic structure, the formation of more capital, an increase in the amount of savings and other changes in aspects of people's economic life. Apart from these changes, economic development also needs to make various changes in various social, political and cultural aspects in the daily life and habits of society.

It can be ascertained that efforts to change these things will cause various reactions such as an increase in tension or disruption in the order of community life, especially those that are still patterned in traditional community life.

Economic development is defined as a process of change or growth that occurs continuously which causes the income per capita of a population of a community to increase in the long term and is accompanied by changes and modernization in the structure and style of economic activity (Sukirno, 2006).

Economic development is a condition needed to improve the quality of human life and the ability to provide production and distribution facilities that are continuous and sustainable. This economic development is a major activity and is absolutely necessary, especially in developing countries in order to improve the level of people's welfare (Suroto, 1992). 
Regional economic development is a process in which the government and the community manage various existing resources and form a partnership pattern between the local government and the private sector to create new jobs and stimulate the development of economic activity or economic growth in the region (Arsyad, 2004).

Meanwhile the local economic development program from the International Labor Organization (ILO) according to Blakely (2002) uses a definition that includes 4 (four) characteristics that can be seen as a participatory development process that encourages partnership arrangements, especially between the private sector and stakeholders. public (stakeholders) from a designated area, so that it is possible to jointly design and implement a common development strategy by utilizing local resources and competitive advantages in a global context with the ultimate goal of creating decent jobs and stimulating economic activity.

Specifically for regional economic development in Manado City, in this study that focuses on disclosing the potential of traditional markets, even though it has traditional local economic characteristics, the existence of traditional markets is still very feasible to become a regional economic potential that is profitable and spectable in increasing regional development. Despite of being in a modern market climate which is full of various facilities for today's marketing activities.

Retail and Retail Business in Indonesia. Retail according to Kotler (2003) is "Retailers or retail store is any business enterprise whose sales volume comes primarily from retailing". Meanwhile, according to Tjiptono (2008) states that retail is all activities of selling goods and services directly to end consumers for personal and household use, not for business purposes. According to Tjiptono, there are four main functions of retail:1.Buy and store goods 2. Transferring the property rights of the goods to the final consumer 3 . Provide information about the nature and use of these goods 4. Providing credit to consumers (in certain cases).

A retail business is a business selling goods and services that have been added value to meet the needs of individuals, families or other end users. Based on the form, retail is broadly divided into two types, which is modern retail and traditional retail.

Modern Market / Retail. Modern markets / retails are not much different from traditional markets, but these types of markets, sellers and buyers do not transact directly, but buyers see the price tag listed on the goods (barcode), are in the building and the service is carried out independently (self-service) or served by a sales assistant.

In the last six years, from 2007-2012, the number of modern retail outlets in Indonesia experienced an average growth of $17.57 \%$ per year. In 2007 , the number of retail businesses in Indonesia was still 10,365 outlets, then in 2011 it reached 18,152 outlets spread across almost all cities in Indonesia.

The growth in the number of outlets is of course followed by sales growth. According to the Indonesian Retail Company Association (Aprindo), retail business growth in Indonesia is between 10 and 15 percent per year. Retail sales in 2006 were still Rp. 49 trillion, and shot up to Rp. 120 trillion in 2011. Meanwhile, in 2012, retail growth is estimated to remain the same, namely $10 \%-15 \%$, or reaching Rp. 138 trillion. The largest amount of income is contributed by hypermarkets, followed by minimarkets and supermarkets.

Indonesia with a population of around 237 million people with a total consumption of around Rp3,600 trillion is a potential market for the modern retail business. This is supported by the shopping behavior of the Indonesian population which has begun to shift, from shopping in traditional markets to modern retail.

With the opening of the entrance for foreign retailers as stated in Presidential Decree No. 118/2000 which has removed the retail business from the negative list for foreign investment, since then foreign retailers have begun to flourish into Indonesia.

The entry of foreign retailers into this business shows that this business is very profitable. However, on the other hand, the entry of foreign hypermarkets, which are increasingly expansive, expanding their outlet networks, could pose a threat to local retailers. Foreign retailers do not only open outlets in Jakarta. For example Carrefour, in the last six years it has penetrated outside of Jakarta, including to Yogyakarta, Surabaya, Semarang, Palembang and Makassar. 
Traditional market. In general, the definition of a market is the activity of sellers and buyers serving buying and selling transactions (www.id.wikipedia.org). A traditional market is a meeting place for sellers and buyers and is characterized by direct seller and buyer transactions and usually a bargaining process. The building usually consists of stalls or outlets, booths and open bases opened by the seller and a market manager.

According to the Presidential Regulation of the Republic of Indonesia Number 112 of 2007 concerning the arrangement and development of traditional markets and shopping centers and modern shops, as well as the Regulation of the Minister of Trade of the Republic of Indonesia Number 70 / M-DAG / PER / 12/2013 concerning guidelines for structuring and fostering traditional markets, shopping centers and modern shops the definition of markets, traditional markets and shopping centers is as follows:

- Market is an area for buying and selling goods with more than one number of sellers, which are referred to as shopping centers, traditional markets, shops, malls, plazas, trade centers;

- Traditional Market is a market that is built and managed by the Government, Regional Government, Private Sector, State-Owned Enterprises and Regional-Owned Enterprises, including cooperation with the private sector with business premises in the form of shops, booths and tents owned or managed by small traders, ongovernmental organizations or small-scale businesses, small capital and with the process of buying and selling merchandise through bargaining;

- Shopping Center is a certain area consisting of one or several buildings erected vertically from one or several buildings erected vertically or horizontally, which are sold or leased to business actors or managed independently to carry out trading activities of goods.

The Existence of Traditional Markets. The study shows some arguments from several researchers or a practitioner regarding the existence and activities of retail business in Indonesia, which is marked by the occurrence of intense competition not only among modern retail business players but what most catches our attention is the fierce competition between modern business actors (hypermarkets, supermarkets and minimarkets) and traditional markets.

Several arguments from researchers suggest that the growth and development of modern markets have become a serious threat to the existence of traditional markets in Indonesia today.

According to Indrawan (2008) and Tambunan et al. (2004) stated that the convenience of shopping that is served and the quality assurance system for products traded by modern markets are fundamental reasons so that traditional market consumers turn to modern markets in carrying out their transaction activities in order to obtain food and daily necessities.

Meanwhile, based on the results of the analysis using the statistical method Suryadarma et al. (2007) and Poesoro (2007) concluded that modernization of places to sell and a better level of cleanliness really attracts consumers' attention in shopping for food and daily necessities served by modern markets, rather than the existence of traditional markets which continue to struggle with the situation and conditions of cleanliness of the location.

Considering that a large number of the workforce will lose their jobs and the impact of these job losses as well as the possibility of losing local cultural identities as traditional market activities are closed, Halim et al. (2007) and Kasali (2006) suggest that the revitalization of traditional markets is urgently needed, which is marked by improvements in the infrastructure for selling places such as repair and arrangement of stalls for selling places, adequate trash cans, representative water installation and distribution and proportional parking area procurement, more safe and adequate.

The impact of these researchers statements was that in 2007 the Indonesian Government issued Presidential Regulation no. 112/2007 as an effort to regulate the main competition that occurs between traditional and modern markets in the retail industry and to protect the existence of traditional markets in Indonesia. 
The central government argues that until now there are still very many Indonesians visiting and carrying out transaction activities in traditional markets in meeting their food and other daily needs, especially for people who have low income levels or are less fortunate.

Furthermore, the Indonesian government is of the opinion that the existence of traditional markets until now has also provided employment for many local residents, traditional markets also function as a place to measure the level of national food availability as well as the standard for determining the selling price of retail products for various food needs and other daily needs.

However, in the field, these central government regulations often conflict with regional regulations made by the provincial, or city / district governments, especially on the grounds of pursuing the target of Regional Real Income (Launa, 2007). The government argues that in this era of decentralization, local governments are required to be able to finance the needs of their respective regions, where with the growth of modern markets it makes it easier for local governments to obtain sources of funds through Regional Real Income in meeting local government needs.

Traditional Market in Manado. The existence of traditional markets in Manado cannot be separated from the history of the formation of Manado in 1623, even before the formation of Manado, it was noted that Manado bay had become a place of competition and a place for transactions of various agricultural commodities such as spices, resin, cloves, nutmeg and vanilla. Chinese, Arabic, Portuguese and Spanish traders with indigenous populations living in the northern tip of the island of Sulawesi (Wahr, 2004; Graafland, 1991).

Since then, the existence of traditional markets has continued to develop and play an economic role, which is as a place for trading local commodities between fellow local residents and immigrants along with the development of Manado.

Along with the development of Manado today, the existence of traditional markets in Manado based on Manado Regional Regulation is managed by a regional company. Currently, this regional company has manages 6 traditional markets and 1 traditional culinary location located on Jalan Roda 45, which is located in the center of Manado with 2,660 traders.

\section{METHODS OF RESEARCH}

The method used in this study is a qualitative research method. Qualitative research is an approach that is also called an investigative approach because researchers usually collect data by face-to-face and interacts with people in the field (McMillan and Schumacher, 2003).

Qualitative research also can be referred to as a type of research where findings are not obtained through statistical procedures or other forms of calculation (Strauss and Corbin, 2003). However, the data collected from qualitative research allows it to be analyzed by means of a calculation.

This study uses two types of data, namely primary data and secondary data. Primary data is data obtained directly from the object of study (not through intermediaries), primary data in this study were obtained through distributing questionnaires and interviews (Simamora, 2008). Data obtained from traditional market retail business (traders or sellers of MSMEs), traditional market consumers, the people of Manado who carry out business activities routinely in traditional markets, such as; Porters, laborers, suppliers of commodity merchandise in traditional markets, traditional market managers / management and scholars.

Secondary data is data obtained by researchers indirectly through intermediary media, which is through research results, books, articles, and various publications and related agencies relevant to the issues raised, such as data obtained from the Central Bureau of Statistics and Development Planning Agency at Sub-National Level (BAPPEDA) Manado.

The research sites in this study are traditional markets: Pasar Bersehati (local trade), which is located at the mouth of the Tondano River, Manado Bay, and Pasar Pinasungkulan (local trade), Karombasan. The reason for these two traditional market locations is that they are used as research sites because these two traditional markets are the oldest (historical) 
traditional markets and the first and second largest based on the large capacity to accommodate the number of traders in Manado based on data obtained from the Market Regional Company Manado.

The method of data collection is carried out by distributing questionnaires and interviews or interviews conducted randomly (randomly) against data sources who want to interact directly and are willing to provide data and information needed in this study. Data taken between peak activities from 06.00 to $10.00 \mathrm{am}$. Data collection using this method is carried out on traditional market consumers, traders / sellers in traditional markets, and the people of Manado who carry out business activities routinely in traditional markets, such as; porters, laborers etc. Meanwhile, the supplier and the manager / management of the traditional market are interviewed based on an agreement on the time and place of the interview.

\section{RESULTS AND DISCUSSION}

The Role of Traditional Markets for Traders. The results show that the existence of traditional markets in Manado has a very vital role for local residents, especially for residents of Manado because it is one of the places or jobs for many residents. This traditional market is able to accommodate and provide job opportunities for thousands of workforce who live in Manado, especially for those who work as traders and people who carry out business activities that are closely related to trading activities in traditional markets such as market workers and intermediary traders. This means that the existence of traditional markets is a solution to the unemployment rate, especially in the public sector.

Based on the data survey, it shows that traders as well as their main families (husband, wife and children) in the two traditional markets depend on all traditional retail business activities in this place. In carrying out activities or business operations in traditional markets, the traders are only supported by their main family. Likewise, capital in carrying out business activities as traders in traditional markets is their own capital or family capital from generation to generation.

Based on the data in this study, assistance from the government, banks or other parties that can assist these traders is urgently needed to develop their businesses that are classified as small and medium enterprises.

Barriers in Traditional Markets for Traders. Traders in traditional markets really expect the handling and construction of infrastructure as soon as possible and structuring the infrastructure with more adequate places to sell, such as representative stalls to sell.

The collection of fees and enforcement of the rules for places to sell in traditional markets is not good and they recommend that the managers of traditional markets in Manado fix it immediately. For the collection of market fees, the survey team saw several times when officers made market charges, traders did not get proof of payment (ticket) for fees, this is very concerned about the occurrence of irregularities or manipulation of fees so that the purpose of collecting these fees will never be achieved.

Likewise the enforcement of place of sale regulations, this study obtained information that traditional market officers often violate the rules or impose double standards on traders in carrying out their business activities. The hygiene of the place of sale, the drainage system of the place of sale and the sanitation toilets handling was poor and had to be followed up immediately.

The Role and Problems of Traditional Markets for Consumers. The consumers of traditional markets are dominated by low income families (57\%) and lower middle income families $(30 \%)$. This indicates that the existence of traditional markets has an important role for most residents of Manado as the main place to shop for food.

It is recognized that the existence of traditional markets is very important, especially in its role as a place to obtain food, clothing and other daily needs, but it must also be recognized that the existence of traditional markets today is not only facing the challenges of competition with modern markets, but also internal problems that continue to decrease the existence of the traditional market itself. 
The Role and Problems of Traditional Markets for Workers. Similar responses were also received by the researcher when conducting a survey on the role and problems of traditional markets for workers. Some workers in traditional markets who had informal conversations with the research team when conducting this survey were family members and acquaintances of traders in traditional markets. According to them, traditional markets are able to provide a place for them to continue to maintain their lives, who on average do not have high educational qualifications.

They hope that management of traditional markets can provide added value to the income levels of these workers. The creation of professions such as market laborers or porters in traditional markets, at least can provide one solution to reduce unemployment in Manado.

Role and Problems of Traditional Markets for Suppliers. The frequency of product supply traded in traditional markets is quite high and is carried out regularly and has been going on for quite a long time. This commodity supply activity has been going on for a long time because based on the results of interviews with these suppliers, information was obtained that they have been carrying out this supply activity for more than 15 years, even this business activity is a legacy from their family.

Furthermore, based on information obtained from suppliers, the lack of infrastructure facilities for unloading supply products and supervision from traditional market managers, especially when unloading because according to them there are often illegal fees or loss of supply products and this is difficult to detect because it is done by individuals.

Other Problems of Traditional Markets. Based on the information and observations of the researcher, another problem that exists in traditional markets is that traditional markets are not only used as a place to make a living by traders but have also been used as their place to living with their families and this has been going on for quite a long time.

Furthermore, based on the observations of the researcher, there is a nominal withdrawal of traditional market fees that is not in accordance with the applicable provisions and is not even carried out according to procedures such as each certain nominal withdrawal does not use a retribution ticket.

In the market, there are some individuals who have the potential to commit acts of violence that lead to actions that interfere with our social security. Even these individuals often impose illegal fees and even ask for gratuities on the grounds of guaranteeing security to traders in traditional markets.

According to information given by traditional market managers, the use of the amount of fees collected from traders in traditional markets is not a rational comparison with the use for maintenance and development of the traditional market infrastructure itself.

\section{CONCLUSION}

This study has analyzed the various economic benefits of the existence of traditional markets for local communities, especially the people of Manado City; retail business actors (traders / sellers - MSMEs) in traditional markets, traditional market consumers, laborers and porters in traditional markets and suppliers (suppliers) are still commodity merchandise in traditional markets.

For traders or sellers, the economic benefits of traditional markets, are able to provide space for those who are also local residents to carry out their activities consistently and permanently. Traditional markets not only provide opportunities to get better profits, but can also guarantee the survival of traders or sellers along with their families. Likewise, for workers and porters, traditional markets provide an opportunity for them to get permanent jobs that guarantee the survival of these workers.

For consumers, the existence of traditional markets can prove and convince consumers as an important place where consumers can shop for all kinds of food, clothing and household needs in general. Especially for consumers who have lower middle income, traditional markets are the main choice as a place to shop for these needs according to their ability or purchasing power. 
Besides being able to provide local products in relatively large quantities and variations and fresh, the existence of traditional markets is also able to provide space and time for the people of Manado, especially consumers to carry out social interaction and communication in accordance with the daily habits and culture of the people of Manado.

For supplier, the existence of traditional markets is very necessary because traditional markets are able to provide a large place to supply their products regularly in large quantities. This condition makes the suppliers, who are mostly farmers and their family members, continue to be motivated to carry out on-farm and off-farm business activities. Along with the regular supply of products in a large capacity with a fairly high frequency of supply and increasing demand, this situation guarantees income stability but also increases income. This condition illustrates that the suppliers could maintain the sustainability of life and to fulfill the needs of their families.

Apart from the very important role and economic benefits for the people of Manado, various problems are faced by traditional markets. For traders or sellers, laborers, porters, suppliers and consumers of traditional markets, they have complained about conditions such as:, infrastructure arrangement, enforcement of regulations, hygiene management, drainage systems, toilet sanitation, lighting facilities, air circulation, and security guarantees. Place to sell that is not in good condition and it is urgent to do repairs and maintenance continuously. Another thing that also urges for serious handling according to traditional market consumers is the problem related with product safety, particularly food products or food ingredients.

Furthermore, based on the information obtained from suppliers, the lack of facilities for unloading supply products and supervision, especially when unloading, because according to them, illegal fees or loss of supply products often occur and this is very difficult to detect because it is done by person with no sense of responsible.

Based on the information from the manager of the traditional market and the observation of the research team, another problem that exists in traditional markets is that traditional markets are not only used as a place to earn a living by traders or sellers but have also been used as a place for living and it has been going on for years. There is a nominal collection that is not in accordance with the applicable regulations and is not even carried out according to procedures such as each certain nominal withdrawal does not use a retribution ticket.

In the market, there are individuals who have the potential to commit acts of violence that lead to actions that interfere with social security. They often impose unclear fees and even ask for gratuities on the grounds of guaranteeing security to traders or sellers in traditional markets.

In addition, the use of the amount of retribution collected from traders or sellers in traditional markets is not a rational comparison with the use for maintenance or development of the traditional market infrastructure itself.

\section{RECOMMENDATIONS}

The existence of traditional markets in Manado, especially in the Bersehati Traditional Market is very complex, which is located at the estuary of the Tondano River, Manado Bay really needs to be maintained as the identity of the City of Manado because the area and the economic activities that occur in that area are historical evidence to the establishment of Manado in 1623 by the founder of Manado, Opo Dotulolong Lasut, even before that year in other historical records for this area has been a place of transaction or trade between Chinese, Arabic and Portuguese immigrants traders since the 1500s.

Traditional markets need to be maintained and develop their roles and functions as a place to shop for food, clothing and other daily household needs for the people of Manado. Traditional markets are able to accommodate a relatively large amount of supply for local products, where the increasing demand for products, especially local products, can excite local producers and suppliers of local products to continue to carry out business activities, which in turn will ensure the sustainability of the local economy. 
It is necessary to re-collect data on traditional market traders or sellers and complete identification cards or member cards based on where they carry out their business activities. This is very necessary, especially in monitoring and controlling the collection of fees for them.

The enforcement of regulations in traditional markets prior to the enactment of new traditional market regulations. The enforcement of the new traditional market rules must be carried out consistently.

Infrastructure renovations in existing traditional markets, especially places for selling and arrangements, hygiene, toilet sanitation, drainage systems, lighting and air circulation, and safety equipment.

Development of new traditional markets should be refer to central government regulations. When a new traditional market is built, it is better not to build it in the form of a multi-store building.

The building of a product safety monitoring for collaboration between traditional market managers and the Food and Drug Supervisory Agency (BPOM), this needs to be done to ensure the safety of food and food products ready for consumption by consumers, this condition can indirectly be a means of promotion to attract consumers to to shop at traditional markets.

It is necessary to improve and organize employees that is more professional and trustworthy, such as collection staff, technicians and officers who are authorized to manage equipment or other company assets who can be trusted and responsible for carrying out their duties.

Organizing traditional market events on a regular basis in collaboration with the Manado Tourism and Culture Board, so that the existence of tourism can also play a role as one of the unique and specific local tourism objects displaying local economic products and culture.

It needs to be restructured for the collection of traditional market fees, the larger allocation is used for repair and maintenance of traditional market infrastructure.

Cleaning competitions between traditional markets, competition for employees of traditional market management units and competitions for the best traditional market traders which are held regularly every year along with the founding day of Manado.

Participation of local governments and their staff in the form of formal and informal cooperation to jointly promote the role and function of traditional markets for local development, economy, social and culture.

Formation of a traditional market community by the people of Manado who love and care about the function and important role of traditional markets in the future.

\section{REFFERENCES}

1. ACNielsen Survey Group, (2013),"The Annual Report of Asia Pacific Retail and Shopper Trends".

2. Antara (2007), "Danamon Corcurning for Revitalitation of Indonesian Pasar", an article on September 7th, 2007, Indonesian version. [online at http://www.antara.co.id/arc/2007/9/7/].

3. Arsyad, L. (2004), Ekonomi Pembangunan, Edisi ke-4, Penerbit STIE Yayasan Keluarga Pahlawan, Yogyakarta.

4. Blakely, E.J and Bradshaw T.K, (2002),"Planning Local Economic Development: Theory and Practice", Sage Publication Inc, C.A. Thausands Odds.

5. Graafland. N. (1991), "De Minahasa: Haar Verleden en haar Tegenwoordige Toestand". Rotterdam: M. Wyt \& Zonen, 1869.

6. Halim. R. E. and Ismaeni. F. (2007), "Analisa Pembentukan Ketertarikan Terhadap Ritel: Agenda Riset bagi Revitalisasi Pasar Tradisional di Indonesia”, Manajemen Usahawan Indonesia Issue Vol 36, LM FEUI, Jakarta, 2007. 
7. Indrawan. R., (2008), "Kebijakan Publik yang Mengatur Sinergitas Pasar Modern dan Tradisional", Wordpress [online at http://rullyindrawan.wordpress.com/2008/12/02/ kebijakan-publik-yang-mengatur-sinergitas-pasar-modern-dan-tradisional/].

8. Kasali. R, (2006), "Mungkinkah Pasar Tradisional Hidup Kembali dan Bersaing dengan Retailer Modern? Implikasi Kebijakan dari Perspektif Konsumen Indonesia", MM-FEUI, Jakarta.

9. Kementerian Perdagangan RI, (2000), “Keppres RI No. 118 Tahun 2000".

10. Kementerian Perdagangan RI, (2007), "Perpres RI No. 112 Tahun 2007".

11. Kompas, (2008), "Mati, 15 \% Pasar Tradisional di Perkotaan", artikel tanggal 29 Maret 2008. [online at Error! Hyperlink reference not valid. read/xml/2008/03/29/ 1625085].

12. Kompas, (2008), "Digusur Hipermarket, 8 Pasar Tradisional Mati" artikel 21 Februari 2008 [online at http:// www.kompas.com/read/xml/2008/02/21 /04464975/digusur.hipermarket. 8.pasar.tradisional.mati].

13. Kotler, Philip, (2003), "Marketing Management", 11th, edition, Prentice Hall, New Jersey.

14. Kuncoro, M. 2009.,"Metode Riset Untuk Bisnis dan Ekonomi", Jakarta: Penerbit Erlangga.

15. Launa., "Menggusur Pasar Tradisional", GP-Ansor, Indonesia, 2007. [online at http://gpansor.org/?p=1748].

16. McMillan , James H. dan Sally Schumacher. (2003),"Research in Education: A Conceptual Introduction", Fifth Edition. New York and London: Logman.

17. Nana Syaodih Sukmadinata dkk. (2001),"Pengendalian Mutu Pendidikan Sekolah Menengah Konsep, Prinsip dan Instrumen", Bandung : Kesuma Karya

18. Pandin, M.R.L. (2009),"The Potrait of Retail Business in Indonesia: Modern Market", Economic Review, No.25.

19. PD. Pasar Manado (2014), "Profile of Pasar in Manado city.

20. Poesoro. A.(2007), "Traditional Markets in the Era of Global Competition", The SMERU Research Institute, Jakarta, 2007.

21. Simamora, B. 2008. Panduan Riset Perilaku Konsumen. Jakarta: Gramedia.

22. Statistics Office of Manado City (2014), "Manado city in Figures 2013", BPS Kota Manado.

23. Sukirno, S. (2006),"Makroekonomi Teori Pengantar, Edisi Ketiga, Penerbit Rajawali Pers, Jakarta.

24. Sugiyono. (2009).,"Metode Penelitian Administrasi“, Bandung: Alfabeta.

25. Suroto (1992),"Strategi Pembangunan dan Perencanaan Kesempatan Kerja", Gadjah Mada University Press, Yogyakarta. Tim Penulis Penebar Swadaya.

26. Suryadarma, et al.,(2007), "The Impact of Supermarkets on Traditional Markets and Retailers in Indonesia's Urban Centers", The SMERU Research Institute, Jakarta.

27. Tambunan. T., Nirmalawati. D., Silondae. A, (2004)., "Kajian Persaingan Dalam Industri Retail”, Komisi Pengawas Persaingan Usaha (KPPU).

28. Tjiptono, F, (2008),"Strategi Pemasaran", Yogyakarta: Andi.

29. Tumbuan, W.J.F.A and Shiratake, Y. (2010),"Sustainability and Advantages of Old Pasar for Local People Under International Free Competition." The Journal of Japan Society for Distributive Sciences (JSDS), No. 26.

30. Tumbuan, W.J.F.A and Shiratake, Y. (2010),"Significance and Developing Conditions of Pasar for the Local Inhabitants."Japanese Journal of Food, Agricultural and Resource Economics, Volume 61, No.1.

31. Wahr, R. C., "History Timeline of Minahasa", The Minahasa, 2004. [online at http://www.theminahasa.net]. 